Syntax Literate: Jurnal Ilmiah Indonesia p-ISSN: 2541-0849

e-ISSN: 2548-1398

Vol. 6, No. 7, Juli 2021

\title{
ANALISIS FACEBOOK DALAM PENYAMPAIAN INFORMASI COVID-19 OLEH PEMERINTAH PROVINSI GORONTALO
}

\section{Cahyadi Saputra Akasse, Muhammad Akbar, Arianto}

Universitas Hasanuddin (UNHAS) Makasar Sulawesi Selatan, Indonesia

Email: cahyadi7akasse@gmail.com, muhakbar6764@gmail.com, arianto0773@gmail.com

\begin{abstract}
Abstrak
Pemerintah melalui Humas saat ini memiliki peran penting dalam hal arus informasi yang kredibel di masyarakat. Hal ini dikarenakan arus informasi di tengah pandemi saat ini dapat berakibat fatal pada masyarakat jika tidak diantisipasi dengan baik oleh Humas. Pemerintah Provinsi Gorontalo melalui Humas melakukan pendekatan mengenai penyampaian informasi ini melalui media sosial, dalam hal ini adalah Facebook. Tujuan dari penelitian ini adalah untuk menganalisis Facebook dalam penyampaian informasi mengenai covid-19 di Provinsi Gorontalo. Untuk mencapai tujuan penelitian tersebut, peneliti menggunakan metode penelitian deskriptif kualitatif dengan jenis pendekatan penelitian studi kasus. Teknik pengumpulan data dilakukan melalui wawancara mendalam (depth interview), observasi partisipan, dan dokumentasi. Kemudian penentuan informan dilakukan melalui Teknik purposive sampling berdasarkan informan yang terlibat secara langsung dengan tujuan penelitian yaitu pejabat dan staff Humas Provinsi Gorontalo. Hasil penelitian menunjukan bahwa dalam proses penyampaian informasi covid-19 di Provinsi Gorontalo terdapat proses dan perencanaan PR dengan model PR empat Langkah, yang terdiri dari (1) mendefinisikan masalah, kemudian (2) perencanaan dan pemograman, selanjutnya (3) mengambil tindakan dan berkomunikasi, dan yang terakhir (4) evaluasi program. Empat Langkah ini telah dijalankan oleh Humas Provinsi Gorontalo dalam upaya menyampaikan informasi mengenai covid-19 di Provinsi Gorontalo.
\end{abstract}

Kata Kunci: humas; media sosial; facebook; covid-19

\section{Abstract}

The government through Public Relations currently has an important role in terms of the flow of credible information in the community. This is because the flow of information in the middle of the current pandemic can be fatal to the public if not well anticipated by public relations. Gorontalo Provincial Government through Public Relations approaches the delivery of this information through social media, in this case Facebook. The purpose of this study is to analyze Facebook in the delivery of information about covid-19 in Gorontalo Province. To achieve the purpose of the study, researchers used qualitative descriptive research methods with this type of case study research approach. Data collection techniques are conducted through depth interviews, participant observations, and documentation.

Akasse, Cahyadi Saputra., Muhammad Akbar dan Arianto (2021) Analisis Facebook Dalam Penyampaian Informasi Covid-19 Oleh Pemerintah Provinsi Gorontalo. Syntax Literate: Jurnal Ilmiah Indonesia. 6(7). http://dx.doi.org/10.36418/syntax-literate.v6i7.3456 2548-1398

Ridwan Institute 
Then the determination of informants is done through purposive sampling techniques based on informants directly involved with the purpose of research, namely officials and public relations staff of Gorontalo Province. The results showed that in the process of conveying covid-19 information in Gorontalo Province there is a PR process and planning with a four-step PR model, consisting of (1) defining the problem, then (2) planning and programming, then (3) taking action and communicating, and the last (4) evaluation of the program.

Keywords: public relations; social media; facebook; covid-19

\section{Pendahuluan}

Pada awalnya Humas dalam penyampaian informasi masih menggunakan media konvensional seperti Koran dalam praktiknya. Hal ini diikuti oleh masyarakat yang masih mengandalkan koran sebagai media utama mereka, beberapa kendala utama dalam menggunakan media cetak ini membuat penyampaian informasi hanya sebatas penyampaian saja dan tidak memerhatikan feedback dari publik. Seiring dengan perkembangan teknologi komunikasi, media sosial muncul sebagai solusi utama dalam kegiatan Humas ini. Kegiatan Humas menggunakan teknologi dalam aktivitas komunikasinya ini merupakan penerapan dari konsep PR Digital yang belakang ini berkembang seiring perkembangan teknologi komunikasi. Dilansir dari hasil survei oleh APJII, pada kuartal kedua tahun 2019 hingga awal 2020 pengguna internet di Indonesia mencapai 196 Juta. Hal ini menjadi alasan bagi PR itu sendiri dalam upaya meningkatkan aktivitas komunikasi mereka.

Media sosial merupakan salah satu bukti nyata perkembangan teknologi komunikasi. Media sosial merupakan suatu medium di internet yang dapat membuat penggunanya mempresentasikan dirinya maupun berinteraksi, bekerja sama, saling berbagi, maupun berkomunikasi dengan pengguna lainnya serta dapat membentuk ikatan sosial secara virtual (Nasrullah, 2017).

Selain itu juga, media sosial dapat memeberikan jangkauan yang lebih baik dari media konvensional, hal ini dikarenakan kemudahan akses nya yang bisa dimanapun dan kapanpun pengguna nya terhubung dengan jaringan internet. Hal ini berbeda jika ingin mengakses informasi melalui media konvensional seperti koran. Perlu waktu hingga sehari atau lebih untuk mengakses informasi terkini, kabar terakhir salah satu koran terbesar di Amerika yaitu Washington Post Express tutup dengan edisi terakhir pada September 2019 lalu. Hal ini menjadi pukulan besar bagi industri koran di seluruh dunia.

Munculnya media sosial ini menjadi tantangan besar bagi industri media konvensional lainnya, bahkan beberapa koran mulai merambah ke media online untuk mempublish berita mereka. Perkembangan teknologi komunikasi menuntut perubahan dalam budaya komunikasi kita, oleh karena itu sangat penting bagi masyarakat untuk dibekali dengan literasi mengenai media sosial.

Saat ini kita perkembangan teknologi komunikasi telah memasuki gelombang keempat (the fourth wave) karena terjadi proses revolusi dimana komunikasi memegang 
peranan yang sangat penting (Nurudin, 2017). Revolusi ini menuntut segala pihak untuk memberikan perhatian lebih terhadap perkembangan teknologi komunikasi, jika tidak maka kita akan jauh tertinggal seperti yang terjadi pada koran Washington Post Express sebelumnya.

Perkembangan teknologi komunikasi ini juga mendorong pemerintah untuk berupaya melakukan pendekatan yang lebih dalam hal pelayanan informasi publik. Salah satunya adalah dengan menggunakan media sosial untuk menyampaikan informasi kepada masyarakat, hal ini merupakan suatu Langkah yang pasti di tengah perkembangan teknologi komunikasi yang begitu pesat. Transisi penggunaan media konvensional ke media sosial ini mulai gencar dilakukan oleh pemerintah, salah satunya adalah Pemerintah Provinsi Gorontalo melalui Biro Humas dan Protokol.

Humas atau biasa disebut juga dengan public relations menurut Wilcox dan Cameron memiliki definisi yaitu sebuah fungsi manajemen terhadap sikap yang direncanakan dan dilakukan secara berkesinambungan oleh organisasi untuk mendapatkan saling pengertian dan simpati dari masyarakat (Wahdaniah \& Wahid, 2020).

(Cutlip, Center, \& Broom, 2011) mendefinisikan PR sebagai fungsi manajemen yang membangun juga mempertahankan relasi yang baik antara organisasi dengan publiknya (Cutlip, Center, \& Broom, 2011). Tugas dan fungsi pokok dari PR ini sangat krusial karena menentukan hubungan baik dari Pemerintah dengan masyarakat. Diluar pemerintahan, Public Relations menjadi wakil dari manajemen perusahaan, memiliki tugas utama yaitu menghubungkan pihak yang berkepentingan, baik internal maupun eksternal perusahaan (Mahriva, 2020).

Kegiatan Humas yang menggunakan media konvensional ini perlahan-lahan dituntut untuk menggunakan media sosial sebagai salah satu upaya dalam pelayanan informasi kepada masyarakat. Tentu saja hal ini harus dibarengi dengan perencanaan yang baik dari Humas itu sendiri.

Humas Provinsi Gorontalo memiliki akun Facebook dalam hal penyampaian informasi kepada masyarakat, saat ini jumlah pengikut nya adalah sebanyak 65 ribu orang. Jumlah tersebut terbilang cukup besar untuk ukuran Provinsi Gorontalo, apalagi akun Facebook ini merupakan akun resmi dari Pemerintah yang paling banyak pengikutnya di Provinsi Gorontalo. Berikut tampilan akun Facebook Humas Provinsi Gorontalo: 

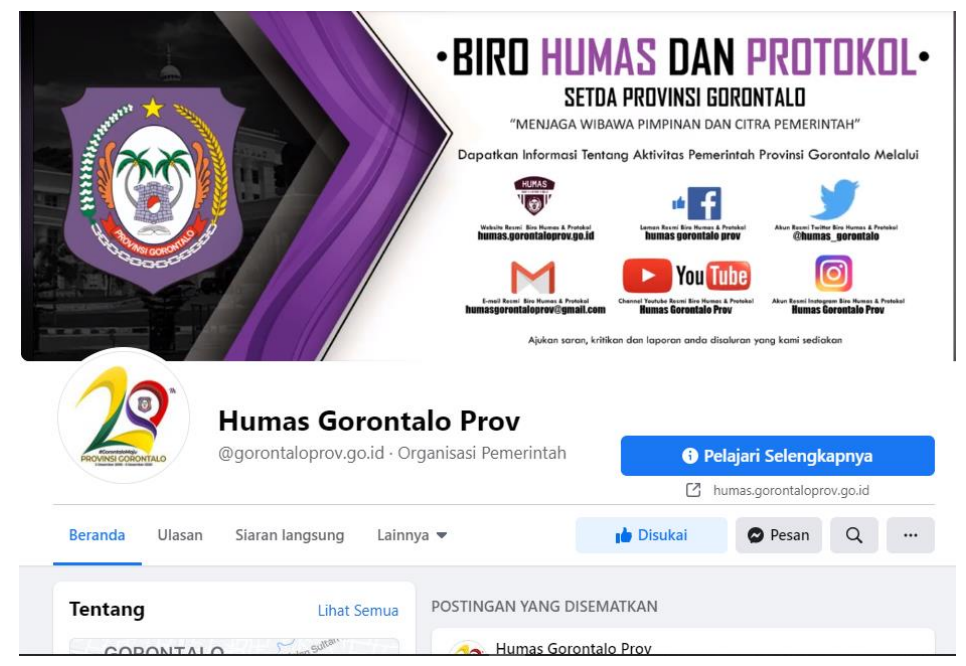

Gambar 1

Akun Facebook Humas Provinsi Gorontalo

Sumber : Facebook Biro Humas dan Protokol Provinsi Gorontalo

Dari beberapa akun media sosial yang dikelola oleh Humas Provinsi Gorontalo, Facebook merupakan media sosial yang paling banyak pengikutnya dan bisa dibilang sebagai media utama dari Humas Provinsi Gorontalo. Hal didukung dengan pengguna Facebook di Gorontalo yang cukup banyak dibandingkan dengan media sosial lainnya.

Pemerintah memiliki peran penting dalam hal penyampaian informasi kepada masyarakat, terlebih lagi di tengah krisis pandemi Covid-19 seperti sekarang. Oleh karena itu dibutuhkan perencanaan khusus oleh pemerintah melalui media sosial yang berbeda dengan penyampaian informasi melalui media konvensional. Dalam krisis pandemi seperti sekarang, pendekatan yang dilakukan oleh Humas berpengaruh besar terhadap efektifnya informasi yang diterima oleh masyarakat. Salah satu hal nya adalah penerapan protokol Kesehatan, informasi yang edukatif dari Humas kemungkinan besar bisa diikuti oleh masyarakat dan tujuan dari pencegahan penyebaran Covid-19 dapat tercapai.

Penggunaan internet atau media sosial oleh Humas ini disebut juga dengan online PR atau electronic public relations (e-PR), yaitu penggunaan teknologi media baru yang berbasis internet secara sistematis dengan tujuan untuk menjaga komunikasi dua arah (Wiratmo, Irfan, \& Kuwatono, 2017).

Transisi dari penggunaan media konvensional ke media sosial ini dikenal dengan Humas 3.0, yaitu penggunaan media sosial dan internet dalam kegiatan Humas, tentu saja monitoring yang biasanya dilakukan Humas secara lansgung bisa dialihkan dengan monitoring melalui media sosial (Simatupang, 2020).

Sebagai data, Covid-19 mulai masuk ke Provinsi Gorontalo pada bulan April 2020 sebagai kasus awal. Pada saat itu konferensi pers langsung disampaikan oleh Gubernur Gorontalo melalui akun Facebook Humas Provinsi Gorontalo. Siaran langsung tersebut mendapatkan perhatian yang sangat besar dari masyarakat Gorontalo, hal ini menandai bertambahnya jumlah pengikut akun media sosial khususnya Facebook secara 
signifikan. Hal ini menjadi indikasi bahwa masyarakat Gorontalo sangat antusias mencari informasi mengenai Covid-19, dan penggunaan media sosial oleh Humas ini menjadikan penyebaran informasi tersebut kredibel, terkini, dan efektif.

Dalam istilah lain, penyampaian informasi ini disebut juga dengan kampanye PR, dengan tujuan yang sama yaitu menyampaikan informasi kepada masyarakat dengan maksud untuk mengubah sikap, opini, serta perilaku khalayak. Kampanye PR merupakan salah satu bentuk komunikasi yang dipahami menjadi solusi dalam mengatasi persoalan-persoalan sosial di masyarakat (Sugianto \& Sembiring, 2018). Kampanye PR dalam artian sempitnya adalah untuk meningkatkan kesadaran serta pengetahuan khalayak untuk membentuk opini yang positif terhadap kegiatan yang dilakukan oleh organisasi (Ruslan, 2013).

Perencanaan dan proses yang dilakukan dengan baik oleh Humas dalam kampanye ini akan menghasilkan tujuan yang baik sehingga bisa memaksimalkan pesan dari kampanye (Kesaulya \& Soewarso, 2019). Dalam penelitian ini penyampaian informasi tersebut terfokus pada informasi mengenai Covid-19 yang disampaikan oleh Humas Provinsi Gorontalo melalui akun media sosial Facebook.

Dalam penerapannya, PR sendiri memiliki beberapa model. Salah satunya adalah model empat Langkah yang dirumuskan oleh (Cutlip, Center, \& Broom, 2011). Keempat proses tersebut terdiri dari (1) mendefinisikan masalah dari PR, (2) perencanaan dan pemograman, (3) Tindakan dan Komunikasi, lalu (4) evaluasi Program. Berikut gambaran proses PR empat Langkah:

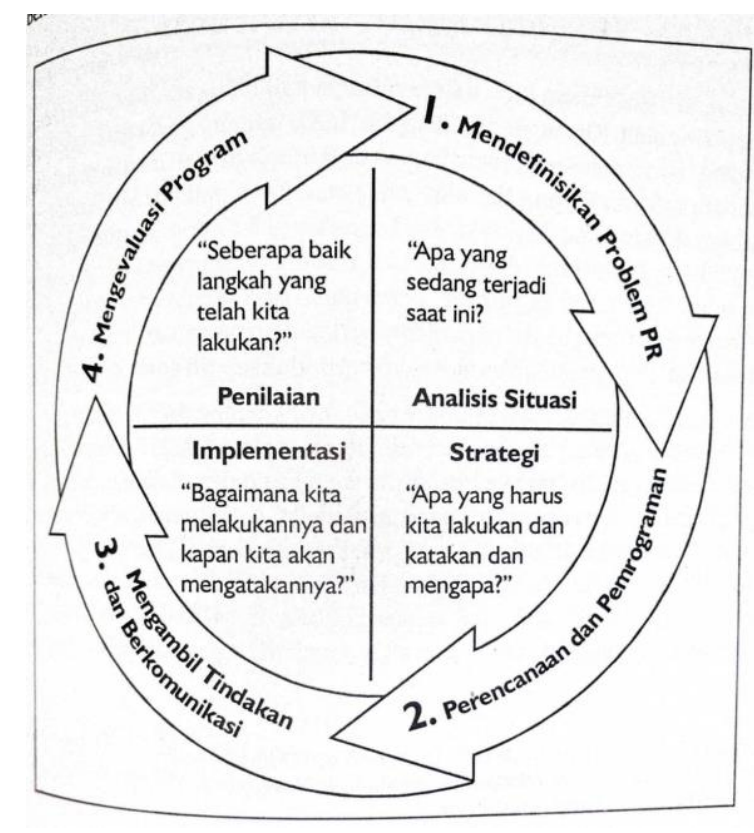

Gambar 2

Tahapan PR Empat Langkah

Sumber: (Cutlip et al., 2011) 
Penelitian tentang penerapan proses PR empat Langkah ini sebenarnya telah dilakukan sebelumnya oleh beberapa peneliti. Hal ini membuktikan bahwa proses ini ialah salah satu proses yang efektif dalam strategi PR yang modern. Salah satunya adalah yang dilakukan oleh Cakra Ningsih mengenai Strategi Humas Dalam Mensosialisasikan Kebijakan UMKM Partai Perindo. Hasil dari penelitian ini menunjukan bahwa Strategi humas dalam menyampaikan kebijakan UMKM Partai Perindo yaitu menggunakan media konvensional seperti media elektronik yaitu iklan di televisi yang ditayangkan di RCTI, Inews, Global TV, MNCTV (Ningsih, 2019).

Selanjutnya adalah penelitian yang berhubungan dengan informasi covid-10 oleh Humas yang dilakukan oleh Yusak Alvian tentang Propaganda Covid-19 terhadap awareness masyarakat surabaya untuk mengikuti program kerja pemerintah. Hasil penelitiannya adalah terdapat pengaruh yang signifikan antara Propaganda Covid-19 terhadap Awareness (kesadaran). Hal ini menunjukkan bahwa Propaganda Covid-19 sangat penting dalam hal meningkatkan kesadaran masyarakat Surabaya mengenai perlindungan terhadap Covid-19 untuk mengikuti program kerja pemerintah (Alvian \& Laudry, 2020).

Dari pemaparan hasil penelitian diatas, peneliti melihat ada beberapa perbedaan yang cukup signifikan dari kedua penelitian diatas. Penelitian pertama menunjukan bahwa strategi Humas melalui proses PR empat Langkah lebih fokus pada gabungan media konvensional dan media sosial. Hal ini berbeda dengan penelitian ini karena lebih fokus pada proses PR empat langkah melalui penerapan nya di media sosial. Kemudian perbedaan pada penelitian yang kedua dengan penelitian ini adalah pada proses penyampaian informasinya. Fokus pada penelitian tersebut adalah bagaimana propaganda mempengaruhi kesadaran masyarakat, sedangkan pada penelitian ini adalah bagaimana penyampaian informasi yang edukatif dan informatif yang disampaikan Humas Provinsi Gorontalo melalui media sosial.

Penggunaan media sosial dalam kegiatan PR belakangan ini mulai diterapkan apalagi di tengah pandemi seperti sekarang. Anjuran untuk bekerja dari rumah atau work from home (WFH) menjadi salah satu alasan terbesarnya, penyampaian infomasi mengenai Covid-19 oleh Humas tidak perlu lagi dilihat melalui koran ataupun media konvensional lainnya. Cukup dengan menggunakan handphone dan internet masyarakat bisa dengan mudah mengakses informasi melalui media sosial. media sosial Facebook sendiri telah menjadi andalan bagi masyarakat Indonesia, Media sosial Facebook ini telah memiliki 2,6 Miliar pengguna di seluruh dunia (Sumartiningtyas, 2020). Selain akrab dengan masyarakat umum, Facebook sendiri sering digunakan oleh para tokoh Daerah hingga tokoh Negara, seperti yang dilakukan oleh Bupati Purwakarta, Dedi Mulyadi (Soffani \& Nugroho, 2019).

Urgensi dari penelitian ini semakin terlihat bahwa di tengah pandemi covid-19 seperti sekarang perlu adanya perencanaan dan proses PR yang strategis dari Humas dalam hal penyampaian informasi. Hal ini dikarenakan peran pemerintah sangat penting dalam menekan penyebaran Covid-19 serta edukasi terhadap masyarakat juga penting agar kesadaran dapat timbul di masyarakat. 
Peneliti menilai bahwa perlunya untuk menganalisis perencanaan dan proses PR yang dilakukan oleh Humas Provinsi Gorontalo, menilai dari adanya data pada November 2020 kemarin mengenai Provinsi Gorontalo yang menjadi daerah dengan penyebaran Covid-19 terendah dari seluruh daerah yang ada di Indonesia (Rahmat, 2020). Dengan begitu bisa menjadi masukan kepada daerah Gorontalo pada khusunya dan daerah lain pada umumnya untuk memperhatikan bahwa penyampaian informasi mengenai Covid-19 dan meningkatkan kesadaran masyarakat sangat penting di tengah pandemi ini.

\section{Metode Penelitian}

Dalam penelitian ini, peneliti menggunakan pendekatan deskriptif kualitatif, yakni penelitian yang bermaksud untuk memahami fenomena tentang apa yang dialami oleh subjek penelitian misalnya perilaku, persepsi, motivasi, tindakan dan lain-lain, serta dengan cara deskripsi dalam bentuk kata-kata dan bahasa, pada suatu konteks khusus yang alamiah dan dengan memanfaatkan berbagai metode alamiah (Moleong, 2013).

Metode penelitian kualitatif menekankan pada subyektifitas peneliti sebagai instrumen dalam penelitian, maka dari itu hasil penelitian ini tidak dapat di generalisir. Pendekatan ini cocok untuk memahami dan mendeskripsikan fenomena-fenomena secara subyektif dan mengutamakan persepsi dari peneliti itu sendiri.

(Cresswell, 2017) mendefiniskan pendekatan kualitatif sebagai suatu proses penelitian untuk memahami masalah-masalah manusia atau sosial dengan menciptakan gambaran menyeluruh serta kompleks yang disajikan dengan kata-kata, melaporkan pandangan terinci yang diperoleh dari para sumber informasi dengan latar yang alamiah (Mulyadi, Basuki, \& Prabowo, 2019).

Teknik penarikan informan dalam penelitian ini menggunakan teknik purposive sampling, yakni pemilihan informan berdasarkan kapabilitas informan terhadap data dari penelitian ini. Informan-informan yang dipilih merupakan orang-orang yang terlibat secara langsung terhadap pengumpulan data dalam penelitian ini.

Kemudian pengumpulan data dalam penelitian ini terdiri dari tiga tahap, tahap pertama yaitu wawancara mendalam (depth interview), lalu tahap kedua yaitu observasi partisipan, dan yang ketiga adalah dokumentasi.

Teknik analisis data dalam penelitian ini menggunakan teknik analisis data kualitatif yang terdiri dari empat tahap. (1) pengumpulan data, (2) reduksi data, (3) penyajian data, (4) penarikan kesimpulan. Data disajikan dalam bentuk uraian atau deskripsi dengan maksud agar data dapat dipahami dan selanjutnya ke tahap berikutnya.

\section{Hasil dan Pembahasan}

Fokus pada penelitian ini adalah untuk menganalisis Facebook dalam penyampaian informasi Covid-19 oleh pemerintah Provinsi Gorontalo, hasil penelitian menunjukkan bahwa dalam penyampaian informasi Covid-19 menggunakan Facebook oleh Pemerintah Provinsi Gorontalo melalui Humas menggunakan tahapan PR empat 
Langkah. Proses ini terdiri dari (1) mendefinisikan problem PR (2) Perencanaan dan Pemograman (3) mengambil tindakan dan berkomunikasi (4) mengevaluasi Program.

\section{A. Mendefinisikan Problem PR}

Dari hasil temuan peneliti melalui wawancara, proses pendefinisian problem dari PR ini dalam hal ini adalah Covid-19. Pemerintah melalui Humas meyakini bahwa di tengah pandemi Covid-19 kebutuhan informasi masyarakat sangat besar dan dituntut untuk menyampaikan informasi secara cepat dan faktual. Oleh karena itu dinilai bahwa penggunaan media sosial sangatlah tepat, secara real time Humas bisa menyampaikan perkembangan terkini mengenai Covid-19 baik kebijakan yang dibuat oleh pemerintah pusat maupun daerah.

Penggunaan Facebook bisa mengatasi masalah kebutuhan informasi yang cepat dari masyarakat. Dengan begitu dapat memaksimalkan pencegahan penyebaran Covid-19 dan menambah kesadaran masyarakat akan Kesehatan.

\section{B. Perencanaan dan Pemrograman}

Proses kedua yaitu perencanaan dan pemograman, proses ini bisa dibilang merupakan proses yang paling krusial. Semua proses membutuhkan perencanaan, maka dari itu tahap perencanaan ini harus diberi perhatian lebih agar keseluruhan proses dapat berjalan dengan baik. Adapun dalam penelitian ini difokuskan pada penggunaan Facebook dalam penyampaian informasi Covid-19 oleh Pemerintah Provinsi Gorontalo

Humas Provinsi Gorontalo melalukan perencanaan dimulai dari menyiapkan konten apa saja yang akan disampaikan. Bahkan pemerintah Provinsi Gorontalo telah membuat peraturan Gubernur mengenai pencegahan covid-19 di Provinsi Gorontalo, selanjutnya konten-konten tersebut dibuat sedemikian rupa sesuai dengan kebutuhan masyarakat. Untuk lebih menarik perhatian masyarakat, Humas Provinsi Gorontalo an begitu masyarakat bisa lebih sadar dan menjaga protokol Kesehatan dan akhirnya tujuan dari penyampaimembuat hiburan seperti meme di Facebook Humas. Konten-konten yang di muat di Facebook dibuat informatif dan edukatif agar masyarakat lebih paham dengan isi pesan, dengan informasi yaitu pencegahan penyebaran Covid-19 dapat tercapai.

Dalam proses perencanaan juga, Humas Provinsi Gorontalo berkoordinasi dengan SKPD terkait agar proses kampanye bisa bersinergi dengan baik. Adanya koordinasi dengan SKPD terkait dapat membuat konten-konten yang dimuat di Facebook Humas Provinsi Gorontalo lebih beragam dan membuat masyarakat lebih tertarik untuk membaca nya.

\section{Mengambil Tindakan dan Berkomunikasi}

Proses ketiga adalah mengambil tindakan dan berkomunikasi. Setelah melakukan perencanaan, proses selanjutnya adalah proses aksi nya. Berdasarkan hasil temuan diatas, bisa dilihat bahwa Humas Provinsi Gorontalo dalam hal penyampaian pesan melalui konten-konten di Facebook memilih pesan yang aktual dan sesuai dengan kondisi sebenarnya di lapangan. Humas Provinsi Gorontalo 
berusaha untuk tidak menggiring opini publik ke arah yang salah, dengan demikian tidak terjadi silang sengkarut informasi di masyarakat.

Dengan adanya informasi dari Humas ini, diharapkan dapat meminimalisir ataupun mencegah informasi-informasi yang menyesatkan di masyarakat terkait Covid-19. Dari hasil temuan diatas juga bisa dilihat bahwa Humas Provinsi Gorontalo menggunakan media sosial Facebook sebagai media utama penyampaian informasi melalui media sosial, hal ini dinilai karena Facebook merupakan media sosial Humas yang paling banyak diikuti oleh masyarakat Gorontalo.

Dalam proses berkomunikasi ini juga ditentukan pemillihan waktu, hal ini dilakukan agar bisa memenuhi kebutuhan informasi masyarakat. Dari hasil wawancara, bisa dilihat bahwa Humas Provinsi Gorontalo selalu memperbaharui informasi secara real time, dalam artian setiap perkembangan kasus dan juga kondisi terkini mengenai Covid-19 di Provinsi Gorontalo dimuat saat itu juga di Facebook Humas. Hal tersebut tentu akan berbeda jika informasi-informasi tersebut disampaikan melalui media konvensional lainnya. Pemilihan media sosial Facebook ini cukup tepat, melihat situasi dan kondisi saat ini yang menuntut informasi yang serba cepat.

Selanjutnya dalam proses berkomunikasi adalah target penyebaran informasi, penentuan target ini penting karena dapat menentukan efektifnya penyampaian informasi yang dilakukan. Dari hasil temuan berupa wawancara, Humas Provinsi Gorontalo menargetkan seluruh masyarakat Gorontalo sebagai target penyampaian informasinya. Namun secara teknis, media sosial membutuhkan jaringan internet untuk mengaksesnya. Selama terhubung dengan internet, seluruh masyarakat Gorontalo bisa mengakses Facebook Humas ini.

Dengan menargetkan seluruh masyarakat Gorontalo, maka masyarakat di perbatasan Provinsi juga termasuk. Sebagai contoh misalnya Pemerintah Provinsi Gorontalo menerapkan Pembatasan Sosial Berskala Besar (PSBB), maka peran masyarakat di sekitar perbatasan Provinsi sangat penting dalam hal ini. Humas Provinsi Gorontalo menambahkan bahwa target dari penyampaian informasi yang dilakukan adalah sebanyak-banyak nya dan seluas-luasnya. Hal ini dikarenakan untuk menambah kesadaran masyarakat akan Covid-19.

\section{Mengevaluasi Program}

Proses terakhir dalam tahapan ini adalah mengevaluasi program. Proses penyampaian informasi juga membutuhkan evaluasi untuk menilai apakah sudah berjalan dengan baik atau tidak. Dikarenakan proses ini adalah proses evaluasi, maka peneliti berinisiatif untuk mendapatkan umpan balik dari masyarakat yang menjadi publik dari Humas Provinsi Gorontalo. Hal ini untuk menilai apakah penyampaian informasi oleh Humas Provinsi Gorontalo sudah berjalan dengan baik dan bisa mengubah sikap, opini, dan perilaku dari masyarakat tersebut sesuai dengan konsep strategi komunikasi.

Humas Provinsi Gorontalo saat ini mengakui bahwa seluruh lapisan masyarakat Gorontalo telah mengetahui apa itu Covid-19, dan ini menjadi bukti 
bahwa penyampaian informasi yang dilakukan melalui Facebook sudah berjalan dengan cukup baik selama ini. Indikasi lainnya adalah masyarakat mulai mematuhi protokol Kesehatan, terbukti hampir seluruh area perbelanjaan dan tempat-tempat umum menyediakan tempat cuci tangan. Pesan-pesan yang disampaikan di Facebook Humas ini juga mendapatkan perhatian publik dengan cara dibagikan di media sosial mereka masing-masing, hal ini semakin menambah efektifnya penyampaian informasi yang dilakukan dan lebih menjangkau masyarakat yang lebih luas.

Setelah mengevaluasi dari internal Humas Provinsi Gorontalo, peneliti mencari data tambahan dari masyarakat yang menjadi publik dari Humas untuk mengetahui sikap, opini, dan perilaku publik setelah mengikuti konten-konten Humas di Facebook.

Pertama mengenai sikap, dari hasil temuan peneliti berupa wawancara Bersama masyarakat ditemukan bahwa terjadi perubahan sikap setelah mengikuti akun Facebook Humas Provinsi Gorontalo. Ada masyarakat yang merasa biasabiasa saja sebelum melihat konten mengenai Covid-19 di Facebook Humas, ada juga yang bersikap acuh tak acuh dengan Covid-19 karena menganggap Covid-19 bukan sesuatu yang berbahaya. Namun setelah melihat konten-konten yang dimuat di Facebook Humas, masyarakat mulai sadar tentang bahaya Covid-19 dan lebih menjaga protokol Kesehatan.

Artinya adalah unsur perubahan sikap terjadi terhadap masyarakat setelah Humas Provinsi Gorontalo menyampaikan informasi Covid-19 di Provinsi Gorontalo melalui media sosial Facebook dalam menyampaikan informasi. Jika mengacu pada konsep strategi komunikasi, hal ini sudah sesuai karena selain menginformasikan mengenai tujuan dari komunikasi, juga menitik beratkan untuk memberikan kesadaran dalam benak masyarakat. Perubahan sikap merupakan salah satu indikasi nya.

Perubahan sikap ini merupakan salah satu Langkah besar dalam upaya pencegahan penyebaran Covid-19 yang dilakukan oleh Humas Provinsi Gorontalo dan juga diharapkan semakin banyak masyarakat yang sadar tentang pencegahan Covid-19 dan penerapan protokol Kesehatan diterapkan dengan baik oleh masyarakat.

Selanjutnya adalah opini, komunikasi yang efektif adalah dapat mengubah opini komunikan. Begitu juga dengan penyampaian informasi, terlebih lagi dilakukan dalam upaya pencegahan Covid-19. Opini masyarakat sangat penting dalam upaya ini, dengan adanya opini masyarakat, pemerintah dapat menilai sejauh mana penyampaian informasi yang dilakukan serta memberikan evaluasi terhadap kinerja pemerintah mengenai pencegahan Covid-19.

Berdasarkan hasil temuan peneliti, terjadi perubahan opini oleh masyarakat setelah mengikuti konten di Facebook Humas Provinsi Gorontalo. Pada awalnya ada yang menganggap Covid-19 sama seperti flu biasa, ada juga yang menimbulkan ketakutan dan kekhawatiran. Hal ini yang menjadi perhatian khusus Pemerintah 
Provinsi Gorontalo, oleh karena itu Humas berupaya untuk menyampaikan informasi secara informatif dan edukatif dengan harapan bisa mencegah hal-hal tersebut terjadi di masyarakat.

Dengan penyampaian secara informatif dan edukatif membuat opini-opini yang tidak tepat di masyarakat dapat diluruskan. Media sosial Facebook menjadi hal yang sangat berpengaruh dalam hal ini, karena secara real time Humas dapat memperbaharui informasi mereka.

Terakhir adalah adanya perubahan perilaku, proses penyampaian informasi dapat dikatakan berhasil jika dapat mengubah perilaku publik. Dalam penelitian ini menekankan pada perilaku publik di tengah pandemi Covid-19, hal ini penting karena sangat mempengaruhi upaya Pemerintah dalam hal pencegahan penyebaran Covid-19.

Berdasarkan hasil temuan peneliti, dalam penyampaian informasi mengenai Covid-19 di Provinsi Gorontalo melalui media sosial Facebook ditemukan bahwa terjadi perubahan perilaku oleh masyarakat setelah mengikuti konten mengenai covid di media sosial Facebook Humas Provinsi Gorontalo. Para informan yang diwawancarai mengakui bahwa konten-konten yang dimuat di media sosial Facebook Humas tersebut dapat mempengaruhi perilaku mereka baik dalam aktivitas sehari-hari maupun dalam hal penerapan protokol Kesehatan.

Mulai timbul kesadaran terhadap Kesehatan setelah mengikuti konten di media sosial Facebook Humas Provinsi Gorontalo, konten-konten yang disampaikan secara informatif dan edukatif tersebut dapat mengedukasi masyarakat serta menghilangkan kekhawatiran berlebih terhadap Covid-19. Pemerintah pusat melalui pemerintah daerah saat ini tengah menerapkan kebiasaan hidup baru atau new normal life, dan perubahan perilaku tersebut tidak akan tercapai jika tidak di komunikasikan dengan baik kepada masyarakat. Hal tersebut yang diupayakan oleh Pemerintah Provinsi Gorontalo melalui Humas, penyampaian informasi yang informatif dan edukatif untuk dapat mengubah perilaku masyarakat dalam penerapan new normal life. Penelitian mengeai praktik PR dalam masa pandemi covid-19 telah dilakukan sebelumnya, salah satunya yang dilakukan oleh Wahdaniah \& Wahid pada tahun 2020 mengenai Strategi Manajemen Krisis Public Relations TNI Angkatan Laut dalam Menghadapi Pandemi Covid-19. Yang membedakan penelitian tersebut dengan penelitian ini adalah lokasi dan objek penelitian. Pada penelitian ini yang menjadi objeknya adalah Humas Provinsi Gorontalo, terlebih lagi yang menjadi hal baru dalam penelitian ini adalah media sosial yang menjadi faktor utama dalam kegiatan penyampaian informasi yang dilakukan oleh Humas Provinsi Gorontalo.

\section{Kesimpulan}

Penyampaian informasi mengenai Covid-19 melalui media sosial Facebook Humas melalui media sosial dalam menyampaikan informasi Covid-19 di Provinsi Gorontalo terdapat proses dan perencanaan PR yang sesuai dengan model PR empat 
Cahyadi Saputra Akasse, Muhammad Akbar, Arianto

langkah. Keempat proses itu yaitu (1) mendefinisikan masalah, kemudian (2) perencanaan dan pemograman, selanjutnya (3) mengambil tindakan dan berkomunikasi, dan yang terakhir (4) evaluasi program. Keempat proses ini telah dijalankan dengan baik oleh Humas Provinsi Gorontalo dalam proses kampanye melalui media sosial dalam menyampaikan informasi mengenai Covid-19 di Provinsi Gorontalo. 


\section{BIBLIOGRAFI}

Alvian, Yusak, \& Laudry, Steven. (2020). Propaganda covid-19 terhadap awareness masyarakat surabaya untuk mengikuti program kerja pemerintah. Jurnal Komunikasi Profesional, 4(1). https://doi.org/10.25139/jkp.v4i1.2569 Google Scholar

Cresswell, J. W. (2017). Research Design: Pendekatan Kualitatif, Kuantitatif, dan Mixed (Edisi Ketiga). Yogyakarta: Pustaka Belajar. Google Scholar

Cutlip, Scott M., Center, Allen H., \& Broom, Glen M. (2011). Effective Public Relations (9th ed.). Jakarta: Kencana Prenada Media Group.

Kesaulya, Charlene Mabelle Reina Ulyanti, \& Soewarso, Kiki. (2019). Perencanaan Kampanye Public Relations "Mari Bersatu Permata Bunda" Untuk Meningkatkan Awareness Masyarakat Sekitar Terhadap Sekolah TK-SD-SMP Permata Bunda. Jurnal Komunikasi Profesional, 3(1), 18. https://doi.org/10.25139/jkp.v3i1.1708 Google Scholar

Mahriva, Mokhammad Naigam. (2020). Corporate Communication Pt. Xl Axiata Tbk. Merespon Masa Krisis Pandemi Virus Covid-19. Wacana: Jurnal Ilmiah Ilmu Komunikasi, 19(1), 137. https://doi.org/10.32509/wacana.v19i1.1044 Google Scholar

Moleong, Lexy J. (2013). Metode Penelitian Kualitatif. Bandung: Remaja Rosdakarya. Mosal. Google Scholar

Mulyadi, Seto, Basuki, A. M. Heru, \& Prabowo, Hendro. (2019). Metode Penelitian Kualitatif dan Mixed Method. Depok: Rajagrafindo Persada. Google Scholar

Nasrullah, Rulli. (2017). Media Sosial: Perspektif Komunikasi, Budaya, dan Sosioteknologi (Nunik Siti Nurbaya, Ed.). Bandung: Simbiosa Rekatama Media. Google Scholar

Ningsih, Cakra. (2019). Strategi Humas Dalam Mensosialisasikan Kebijakan Umkm Partai Perindo. Jurnal Pustaka Komunikasi, 02(01), 13. https://doi.org/https://doi.org/10.32509/pustakom.v2i1.863 Google Scholar

Nurudin. (2017). Perkembangan Teknologi Komunikasi (1st ed.). Jakarta: PT. Rajagrafindo Persada.

Rahmat, Yudi. (2020). Gorontalo Urutan Pertama Persentase Kasus Covid-19 Terendah.

Ruslan, Rosady. (2013). Kiat dan Strategi Kampanye Public Relations. Jakarta: Rajagrafindo Persada. Google Scholar

Simatupang, Oktolina. (2020). Kompetensi Humas Pemerintah Dalam Menghadapi Era Industri 4.0. Jurnal PIKOM (Penelitian Komunikasi Dan Pembangunan), 21(1), 
85. https://doi.org/10.31346/jpikom.v21i1.2503

Soffani, Ainun, \& Nugroho, Catur. (2019). Unsur Budaya Dalam Media Sosial: Studi Pada Facebook Kang Dedi Mulyadi. Jurnal Manajemen Komunikasi, 03(02). https://doi.org/https://doi.org/10.24198/jmk.v3i2.12936 Google Scholar

Sugianto, Arifin, \& Sembiring, Antonius Wilson. (2018). Kampanye Public Relations Dalam Membentuk Sikap Positif Khalayak (Studi pada Kampanye Kawasan Bebas Rokok yang Diimplementasikan oleh Universitas Sari Mutiara Indonesia). Jurnal Lensa Mutiara Komunikasi, 2(1). 45-60. Google Scholar

Sumartiningtyas, Holy Kartika Nurwigati. (2020). Era Media Sosial Facebook Jadi yang Terpopuler di Indonesia.

Wahdaniah, Infra, \& Wahid, Umaimah. (2020). Strategi Manajemen Krisis Public Relations TNI Angkatan Laut dalam Menghadapi Pandemi Covid-19. Warta ISKI, 3(2), 160-167. https://doi.org/10.25008/wartaiski.v3i02.72 Google Scholar

Wiratmo, Liliek Budiastuti, Irfan, Noor, \& Kuwatono, Kuwatono. (2017). Website Pemerintah Daerah sebagai Sarana Online Public Relations. Jurnal Aspikom, 3(2), 14. Google Scholar

\section{Copyright holder:}

Cahyadi Saputra Akasse, Muhammad Akbar, Arianto (2021)

\section{First publication right:}

Syntax Literate: Jurnal Ilmiah Indonesia

This article is licensed under: 